\title{
Chapter 9 \\ Article 14: The Right to Freedom of Thought, Conscience, and Religion
}

\section{Roberta Ruggiero}

1. States Parties shall respect the right of the child to freedom of thought, conscience and religion.

2. States Parties shall respect the rights and duties of the parents and, when applicable, legal guardians, to provide direction to the child in the exercise of his or her right in a manner consistent with the evolving capacities of the child.

3. Freedom to manifest one's religion or beliefs may be subject only to such limitations as are prescribed by law and are necessary to protect public safety, order, health or morals, or the fundamental rights and freedoms of others.

\section{What Did Children Say?}

'There would be places of worship and religious texts from a variety of religions in each municipality.' (Western Europe/Other)

'Libraries have child-friendly access to different religious texts.' (Western Europe/Other)

'We would know the right is being protected by 'there being available world religion classes in schools for students to inform themselves, but also

(continued)

\footnotetext{
R. Ruggiero $(\bowtie)$

Centre for Children's Rights Studies, University of Geneva, Geneva, Switzerland e-mail: roberta.ruggiero@unige.ch 
the possibility to opt out of any religion class (in schools).' '(Western Europe/ Other)

'Laws are developed to prevent/discourage imposing religion on someone, partner, parents.' (Eastern Europe)

\section{Overview}

Article 14 of the Convention attributes to children the fundamental civil right to freedom of thought, conscience, and religion. As is the case for other autonomy and participation rights in the Convention, namely Articles 12 through 17, it represents a significant evolution for the recognition of children as an autonomous subject of law (Brems, 2005, p. 1).

It recognises the rights and duties of the parents, but in addition, it attributes them a 'guiding role.' Article 14(2) echoes Article 5 and reiterates the paradigm shift of the Convention, based on the respect for the responsibilities, rights, and duties of parents, ${ }^{1}$ to provide, in a consistent manner consistent with the evolving capacities of the child, 'appropriate direction and guidance in the exercise by the child's rights as recognized in the CRC' (Brems, 2005).

Eva Brems, in her commentary on Article 14, defines the parental right outlined in Article 14(2) as an 'accessory to the child's right, rather than an autonomous right on an equal footing.' The author justifies this assumption because, during the drafting of Article 14, the Working Group adopted at first reading a version including a fourth paragraph modelled on Article 18(4) of the ICCPR, ${ }^{2}$ but adding the child's choice on equal basis with that of the parents. ${ }^{3}$ That this fourth paragraph was dropped in the final version underlines the intent of the drafters to attribute to children an autonomous position in the exercise of their rights.

Although Article 14(1) and (3) are in line with the wording of Article 18 of the ICCPR, Article 14(2) has a different phrasing, in comparison with the other international treaties and conventions, and it fails to include explicitly the children's right to adopt or change their religion.

\footnotetext{
${ }^{1}$ Included members of the extended family or community as provided for by local custom, legal guardians or other persons legally responsible for the child.

${ }^{2}$ Which reads as follows: 'The States Parties to the present Covenant undertake to have respect for the liberty of parents and, when applicable, legal guardians to ensure the religious and moral education of their children in conformity with their own convictions'.

${ }^{3}$ 'The States Parties shall equally respect the liberty of the child and his parents and, where applicable, legal guardians, to ensure the religious and moral education of the child in conformity with convictions of their choice' (Detrick et al., 1992, p. 246).
} 


\section{General Principles}

Article 2 All rights should be recognised for each child without discrimination on the grounds of religion or opinions (including conviction and thought). Some groups of children can face direct or indirect discrimination in the exercise of Article 14. These include children belonging to a minority religious group, children with a specific diet regime imposed by their religion or belief, children wearing headscarves or other religious clothing or symbols, or in the exercise of conscientious objection in relation to compulsory education. ${ }^{4}$ Article 14, in combination with Article 2 , requires action from States Parties to remove all these forms of discrimination (Brems, 2005, p. 9; UN Committee on the Rights of the Child, 2016, para. 43). ${ }^{5}$

Article 3 The best interests of the child should be a primary consideration in all actions concerning children. In relation to Article 14, the preservation of the identity of the child (Article 8) plays a key role and must be respected and taken into consideration in the assessment of the child's best interests. For example, when considering a foster home or placement for a child, 'due regard shall be paid to the desirability of continuity in a child's upbringing and to the child's ethnic, religious, cultural and linguistic background (Article 20) and the decision-maker must take into consideration this specific context when assessing and determining the child's best interests' (UN Committee on the Rights of the Child, 2013, para. 55).

Article 6 Article 14 contributes to the preservation and growth of the identity of the child. Its full exercise allows the child to achieve his/her complete development.

Article 12 The child's views must be taken seriously. States Parties and parents should preserve the right of all children to express their views freely 'in all matters affecting the child', which includes in matters of freedom of thought, conscience, and religion, in terms of choice and manifestation (in particular in relation to conscience and religion). In addition, it introduces the obligation to provide opportunities to be heard in any judicial or administrative proceedings affecting the child.

\section{Articles Related or Linked to Article 14}

Articles 5 and 18 are echoed by Article 14 (2) and require respect for the role of the parents' direction to the child 'in a manner consistent with the evolving capacities of the child' (Brems, 2005, p. 25).

\footnotetext{
${ }^{4}$ For more details, see the Report of the Special Rapporteur on freedom of religion or belief (Bielefeldt, 2012, paras. 51-59) and the Implementation handbook for the convention on the rights of the child (Hodgkin et al., 2007, pp. 186-87, 191-92).

${ }^{5}$ See, for example, Concluding Observations for Poland (UN Committee on the Rights of the Child, 2002a, paras. 32, 33) and Tunisia (UN Committee on the Rights of the Child, 2002b, paras. 29, 30).
} 
Article 8 protects the child's rights to preserve his or her identity, including religious identity.

Article 12 protects the rights to form and express views, to which is linked the concept of freedom of thought (Hodgkin et al., 2007, p. 178).

Article 13 protects freedom of expression, which extends to expression in the religious sphere (Detrick et al., 1992, p. 247; UN Commission on Human Rights, 1989, para. 284).

Article 15 protects freedom of association and of peaceful assembly, which extends to the context of religion.

Article 16 protects the child's privacy right, which in the religious sphere implies that children cannot be forced to reveal their thoughts (Brems, 2005, p. 8).

Article 17 applies to adequate information about religious matters.

Article 19 protects the child from all forms of physical or mental violence, including those perpetrated by States Parties and parents in exercising their guiding role under Article 14(2).

Article 20(3) provides that alternative care arrangements must pay due regard to the child's religious background and give continuity to this and the child's cultural identity (Brems, 2005, p. 8; Hodgkin et al., 2007, pp. 179, 182).

Article 23 for its emphasis on the right to specialised supports for the disabled child's spiritual development and fullest possible individual development.

Article 27 also contextualises Article 14 rights in relation to the right to a standard of living 'adequate for the child's physical, mental, spiritual, moral and social development.'

Articles 28 and 29, and in particular Article 29(1)(d): The latter stipulates that education shall be directed to the 'preparation of the child for responsible life in a free society, in the spirit of understanding, peace, tolerance, equality of sexes, and friendship among all peoples, ethnic, national and religious groups and persons of indigenous origin' (Brems, 2005, pp. 8, 9; Hodgkin et al., 2007, pp. 176, 177). ${ }^{6}$

Article 30 protects the right of children belonging to religious minorities to profess and practice their own religion (Brems, 2005, p. 8; Hodgkin et al., 2007, pp. 179, 182; UN Committee on the Rights of the Child, 2009, para. 16).

Article 38 and Optional Protocol to the Convention on the Rights of the Child on the involvement of children in armed conflict have some relevance for the protection of religious freedom and freedom of conscience:

- Article 38 and the Optional Protocol both refer to the international humanitarian law, which includes some provisions in respect of the 'religious freedom of prisoners of war, civilian internees, protected persons and population of occupied territories' (Brems, 2005, pp. 8, 9)

\footnotetext{
${ }^{6}$ The Article 29 (2) provision requires specific mention here since it is the UNCRC echo to ICCPR Article 18(4) and ICESCR Article 13(3) expressed not as a right of parents but as the right of individuals and bodies to establish separate educational institutions, for instance vocational or denominational schools.
} 
- With reference to the freedom of conscience, an important aspect is the 'conscientious objection' to military service. In particular, for those countries that include some form of military training within the education system, when compulsory this could be in conflict with Article 14 (Hodgkin et al., 2007, pp. 177, 178).

\section{Relevant Instruments}

The civil right to freedom of thought, conscience, and religion is upheld for everyone in the following international documents:

- UN Universal Declaration of Human Rights (1948), Article 18

- UN Convention Against Discrimination in Education (1960)

- International Covenant on Civil and Political Rights (1966), Article 18

- International Covenant on Economic, Social and Cultural Rights (1966), Article $13(3)^{7}$

- International Convention on the Elimination of all forms of Racial Discrimination (1966), Article 5

- International Convention on the Protection of the Rights of All Migrant Workers and Members of Their Families (1990), Article 12

- European Convention on Human Rights (1950), Article 9

- Charter of Fundamental Rights of the European Union (2000), Article 10

- American Convention on Human Rights 'Pact of San Jose, Costa Rica' (B-32) (1978), Article 12

- African Charter on Human and Peoples' Rights (1981), Article 8

- African Charter on the Rights and Welfare of the Child (1990), Article 9. It mentions only a parental duty and not a right.

\section{Attributes}

\section{Attribute One: The Scope of Children's Freedom of Thought, Conscience, and Religion}

Due to the similar wording of Article 14(1) and (3) of the Convention to Article 18(1) and (3) of the ICCPR, in most situations the Committee provides interpretation

\footnotetext{
${ }^{7}$ Article 13(3) CESCR: 'The States Parties to the present Covenant undertake to have respect for the liberty of parents and, when applicable, legal guardians to choose for their children schools, other than those established by the public authorities, which conform to such minimum educational standards as may be laid down or approved by the State and to ensure the religious and moral education of their children in conformity with their own convictions'.
} 
and recommendations quoting international instruments and recommendations issued by other treaty bodies in relation to Article 18 of the ICCPR. With reference to state legal regulation of Article 14, the Committee refers to the Human Rights Committee General Comment no 22 on Article 18 ICCPR (1993). ${ }^{8}$ In it, the Human Rights Committee states that, 'the freedom of thought and conscience or on the freedom to have or adopt a religion or belief of one's choice does not permit any limitations whatsoever. ${ }^{9}$ The use of this interpretative approach to Article 14 by the Committee clarifies the position of the States Parties, which hold not only an obligation to respect but also an obligation to fulfil and protect the exercise of the right of the child to freedom of thought, conscience, and religion (Hodgkin et al., 2007, p. 186; Nowak, 2005, p. 311).

Consequently, the issues that may affect the full enjoyment of Article 14 are aspects of major concern for the Committee. Based on its Concluding Observations, they focus on the necessity of:

- Enacting legislation 'guaranteeing the freedom of religion for those under 18 years' (UN Committee on the Rights of the Child, 2005a, paras. 44, 45)

- Taking effective measures 'to prevent and eliminate all forms of discrimination on the grounds of religion or belief' (UN Committee on the Rights of the Child, 2000a, paras. 35, 36, 2005b, paras. 37, 38, 2005c, paras. 41, 42)

- Promoting 'religious tolerance and dialogue in society' (UN Committee on the Rights of the Child, 2000a, paras. 35, 36, 2005b, paras. 37, 38, 2005c, paras. 41, 42, 2006, paras. 34, 35)

- Repealing any ban instituted 'by local authorities on children of any age form participating in religious activities' (UN Committee on the Rights of the Child, 2005a, paras. 44, 45)

- Preventing, prohibiting and punishing 'any violent attack against religious activities, including demolition of places of worship' (UN Committee on the Rights of the Child, 2006, paras. 34, 35).

\section{Attribute Two: Protection Against State Indoctrination}

The Committee dedicates particular attention to the risk of state indoctrination of moral and religious beliefs in school systems. The Committee issued

\footnotetext{
${ }^{8}$ To be integrated with the 1981 Declaration on the Elimination of All Forms of Intolerance and of Discrimination Based on Religion or Belief, General Assembly resolution 36/55, the Resolution Commission on Human Rights 2000/33, the Human Rights Committee's General Comment no. 22, and concurring with the findings of the Human Rights Committee, ICCPR /C/79/Add.25 and the Committee on Economic, Social and Cultural Rights, E/C.12/1993/7.

${ }^{9}$ This is assured by article 18 ICCPR (and Article 14 of the Convention) and by the right to privacy set out in article 17 of the ICCPR (child's right to privacy is echoed in article 16 of the Convention) (United Nations, 2006, p. 195).
} 
recommendations about two specific situations: freedom of religion and conscientious objection in school systems.

In its first General Comment, issued in 2001, on the aims of education, the Committee emphasises that 'children do not lose their human rights by virtue of passing through the school gates,' and specific attention should be dedicated to children's views in this setting (2001, para. 8). As a consequence, it is necessary to take all required measures to ensure that 'children may choose whether to participate in classes on religion or atheism' (UN Committee on the Rights of the Child, 2005a, paras. 44, 45). ${ }^{10}$ This should also apply to the content of moral education, as explained by the Human Rights Committee, which clarifies that Article 18(4) 'permits public school instruction in subjects such as the general history of religions and ethics if it is given in a neutral and objective way.' Therefore, for the Human Rights Committee, 'public education that includes instruction in a particular religion or belief is inconsistent with Article 18(4) unless provision is made for non-discriminatory exemptions or alternatives that would accommodate the wishes of parents and guardians' (United Nations, 2006, p. 196). Moreover, a provision offering stronger protection against state indoctrination is included in Article 5(1) (b) of the UN Convention against Discrimination in Education (1960). It refers to procedures in domestic legislation that must ensure 'the religious and moral education of the children in conformity with their own convictions; and no person or group of persons should be compelled to receive religious instruction inconsistent with his or their conviction. ${ }^{11}$

With reference to the freedom of conscience, an important aspect is the conscientious objection to military service when it is not based on religion, but rather on other personal convictions such as pacifism. For those countries that include some form of military training within the education system, when this is compulsory, it could be in conflict with Article 14 (Brems, 2005, pp. 14-15).

\section{Attribute Three: Protection Against Religious and Moral Instruction Imposed by Parents}

Article 14 of the Convention is the object of the largest number of reservations or declarations made by States Parties. Some of these reservations or declaration are

\footnotetext{
${ }^{10}$ This applies also when the compulsory school curriculum does not provide for children's freedom of religion (UN Committee on the Rights of the Child, 2004, paras. 31, 32, 2005d, paras. 25, 26), or religious education in schools is not compulsory or there are arrangements for exemption but the choosing process is not adequate to achieve freedom of religion (UN Committee on the Rights of the Child, 2000b, paras. 26, 27, 2002a, paras. 32, 33, 2003, paras. 29, 30, 2005e, para. 20) For a larger analysis, see Implementation handbook for the convention on the rights of the child (Hodgkin et al., 2007, pp. 189-191).

${ }^{11}$ Article 5(1)(b) of the UN Convention against Discrimination in Education (1960) adopted by the General Conference of the United Nations Educational, Scientific and Cultural Organization on 14 December 1960.
} 
meant to uphold parental rights and authority in relation to the civil rights of children (including Articles 13 and 15). Indeed, the most difficult issues are those in which children's freedom of thought, conscience, and religion are opposed to the rights and interests of their parents or legal guardians. This situation is addressed by Article 14 (2). Unfortunately, little support for the interpretation of this provision can be found in the international treaties.

With reference to the role of parents, in General Comment no. 20 the Committee urges States Parties to withdraw any reservations to Article 14 of the Convention and clarifies that "it is the child who exercises the right to freedom of religion, not the parent, and the parental role necessarily diminishes as the child acquires an increasingly active role in exercising choice throughout adolescence' (2016, para. 43).

However, based on the wording of Article 14 of the Convention, Eva Brems notes the child's freedom of thought, conscience and religion 'can be restricted by their parents, and that States Parties may sometime interfere in the parents' exercise of their duties in this respect' in order to determine the child's best interest, and allow the child to receive a religious and moral education better in line with their own convictions. $^{12}$

In these specific cases, the States Parties have the responsibility to ensure that the child is not compelled to receive religious or moral instruction inconsistent with their convictions and to protect the child from all forms of physical or mental violence, including those perpetrated by parents in providing directions under Article 14(2).

\section{References}

Bielefeldt, H. (2012). Elimination of all forms of religious intolerance, A/71/269. UN. Accessed October 24, 2020, from http://digitallibrary.un.org/record/839421.

Brems, E. (2005). A commentary on the United Nations Convention on the Rights of the Child, Article 14: The right to freedom of thought, conscience and religion. Brill Nijhoff. Accessed October 23, 2020, from https://brill.com/view/title/11608.

Detrick, S., Doek, J. E., \& Cantwell, N. (1992). The United Nations Convention on the Rights of the Child: A guide to the "Travaux Préparatoires." Martinus Nijhoff.

Hodgkin, R., Newell, P., \& UNICEF. (2007). Implementation handbook for the Convention on the Rights of the Child (3rd ed.). UNICEF. Accessed September 21, 2020, from https:// digitallibrary.un.org/record/620060? $\mathrm{ln}=\mathrm{en}$

Nowak, M. (2005). U.N. Covenant on Civil and Political Rights: CCPR commentary. N.P. Engel.

UN Commission on Human Rights. (1989). Report of the Working Group on a Draft Convention on the Rights of the Child, E/CN.4/1989/48. Accessed October 12, 2020, from https://digitallibrary. un.org/record/57437? $\ln =\mathrm{en}$.

UN Committee on the Rights of the Child. (2000a, June 28). Concluding observations: Iran, CRC/C/15/Add.123. Accessed October 12, 2020, from https://digitallibrary.un.org/record/ $422916 ? \ln =\mathrm{en}$.

\footnotetext{
${ }^{12}$ Convention against Discrimination in Education Adopted by the General Conference at its eleventh session, adopted on 14 December 1960 and entered into force on 22 May 1962.
} 
UN Committee on the Rights of the Child. (2000b, June 28). Concluding observations: Norway, CRC/C/15/Add.126. Accessed October 23, 2020, from https://digitallibrary.un.org/record/ $422919 ? \ln =$ en.

UN Committee on the Rights of the Child. (2001, April 17). General comment no. 1 (2001) Article 29 (1): The aims of education, CRC/GC/2001/1. Accessed October 10, 2020, from https:// digitallibrary.un.org/record/447223? $\mathrm{ln}=\mathrm{en}$.

UN Committee on the Rights of the Child. (2002a, October 30). Concluding observations: Poland, CRC/C/15/Add.194. Accessed October 24, 2020, from https://digitallibrary.un.org/record/ $481017 ? \ln =$ en.

UN Committee on the Rights of the Child. (2002b, June 13). Concluding observations: Tunisia, CRC/C/15/Add.181. Accessed October 23, 2020, from https://digitallibrary.un.org/record/ $473484 ? \ln =$ en.

UN Committee on the Rights of the Child. (2003, March 18). Concluding observations: Italy, CRC/C/15/Add.198. Accessed October 12, 2020, from https://digitallibrary.un.org/record/ $497795 ? \ln =$ en.

UN Committee on the Rights of the Child. (2004, February 26). Concluding observations: Armenia, CRC/C/15/Add.225. Accessed October 11, 2020, from https://digitallibrary.un.org/record/ $530794 ? \ln =$ en.

UN Committee on the Rights of the Child. (2005a, November 24). Concluding observations: China, CRC/C/CHN/CO/2. Accessed October 24, 2020, from https://digitallibrary.un.org/ record $/ 575653 ? \ln =$ en.

UN Committee on the Rights of the Child. (2005b, October 12). Concluding observations: Algeria, CRC/C/15/Add.269. Accessed October 24, 2020, from https://digitallibrary.un.org/record/ $570473 ? \ln =$ en.

UN Committee on the Rights of the Child. (2005c, March 31). Concluding observations: Iran, CRC/C/15/Add.254. Accessed October 12, 2020, from https://digitallibrary.un.org/record/ $557400 ? \ln =$ en.

UN Committee on the Rights of the Child. (2005d, September 21). Concluding observations: Costa Rica, CRC/C/15/Add.266. Accessed October 11, 2020, from https://digitallibrary.un.org/record/ $570468 ? \ln =$ en.

UN Committee on the Rights of the Child. (2005e, September 21). Concluding observations: Norway, CRC/C/15/Add.263. Accessed October 23, 2020, from https://digitallibrary.un.org/ record $/ 569887 ? \ln =$ en.

UN Committee on the Rights of the Child. (2006, June 2). Concluding observations: Turkmenistan, CRC/C/TKM/CO/1. Accessed October 23, 2020, from https://digitallibrary.un.org/record/ $580376 ? \ln =\mathrm{en}$.

UN Committee on the Rights of the Child. (2009, February 12). General comment no. 11 (2009), Indigenous children and their rights under the Convention, $C R C / C / G C / 11$. Accessed October 24, 2020, from https://digitallibrary.un.org/record/648790? $\ln =\mathrm{en}$.

UN Committee on the Rights of the Child. (2013, May 29). General comment no. 14 (2013) on the right of the child to have his or her best interests taken as a primary consideration (art. 3, para. 1), $C R C / C / G C / 14$. Accessed October 12, 2020, from https://digitallibrary.un.org/record/ $778523 ? \ln =$ en.

UN Committee on the Rights of the Child. (2016, December 6). General comment no. 20 (2016) on the implementation of the rights of the child during adolescence, CRC/C/GC/20. Accessed October 12, 2020, from https://digitallibrary.un.org/record/855544? $1 \mathrm{n}=\mathrm{en}$.

United Nations. (2006). Compilation of general comments and general recommendations adopted by human rights treaty bodies, HRI/GEN/1/Rev. 8. UN. Accessed April 19, 2020, from http:// digitallibrary.un.org/record/576098. 
Open Access This chapter is licensed under the terms of the Creative Commons Attribution 4.0 International License (http://creativecommons.org/licenses/by/4.0/), which permits use, sharing, adaptation, distribution and reproduction in any medium or format, as long as you give appropriate credit to the original author(s) and the source, provide a link to the Creative Commons license and indicate if changes were made.

The images or other third party material in this chapter are included in the chapter's Creative Commons license, unless indicated otherwise in a credit line to the material. If material is not included in the chapter's Creative Commons license and your intended use is not permitted by statutory regulation or exceeds the permitted use, you will need to obtain permission directly from the copyright holder. 